\title{
Regulatory Tools to Encourage FinTech Innovations: The Innovation Hub and Regulatory Sandbox in International Practice*
}

\author{
Péter Fáykiss - Dániel Papp - Péter Sajtos - Ágnes Törös
}

In our study, we assess the regulatory tools that can be applied to encourage FinTech innovations, also focusing on the aims of financial stability. After reviewing the opportunities and risks of FinTech innovations from micro- and macro-prudential aspects and in terms of consumer protection, we present the kinds of possible regulatory responses to the challenges raised by FinTech phenomena and the regulatory tools which are applied in international practice. We analyse these practices from the aspect of legal implementation, detailing their similarities and differences. Finally, we briefly present Hungarian regulatory initiatives encouraging FinTech innovations. An assessment of international cases reveals that there is no generally effective, standardised solution that meets every geopolitical requirement: when the concepts are developed, the special features of the financial intermediary system of the given country and the level of financial culture must also be taken into account.

Journal of Economic Literature (JEL) codes: K2, G28, F39

Keywords: financial stability, fintech, innovation hub, regulatory sandbox

\section{Introduction}

Until the end of the 20th century, the financial system was a trailblazer in the application of technological innovations, but at the beginning of the 21st century this was less typical. Starting from the 1960s, the banking system has relied strongly on innovations related to new technological solutions: key developments in past decades include the credit card, the ATM and the electronic system used for the management of settlements and these all clearly demonstrate the openness of the banking system to innovations, but a similar approach was dominant in the capital

\footnotetext{
* The papers in this issue contain the views of the authors which are not necessarily the same as the official views of the Magyar Nemzeti Bank.
}

Péter Fáykiss Director of the Magyar Nemzeti Bank. E-mail: faykissp@mnb.hu Dániel Papp is a Lawyer of the Magyar Nemzeti Bank.E-mail: pappd@mnb.hu Péter Sajtos is a Junior Analyst at the Magyar Nemzeti Bank. E-mail: sajtosp@mnb.hu Ágnes Törös is a Senior Analyst at the Magyar Nemzeti Bank. E-mail: torosa@mnb.hu

The Hungarian manuscript was received on 28 March 2018.

DOI: http://doi.org/10.25201/FER.17.2.4367 
market and insurance sector as well (Arner et al. 2016, MNB 2017). However, in recent years the extremely rapid development and application of information and communication technologies have made a whole set of innovations essential in various sectors of the economy. The wide use of digital technologies is increasingly incorporated into everyday life, and it is slowly becoming essential for the society to be able to use the services via digital channels as well, the sector of financial products and services cannot avoid being subject to this trend. However, while technological innovations were incorporated into the operation of players in several other sectors, financial institutions and especially the banking system have not been able to deeply integrate such innovations into their daily operations (EY 2016).

After the crisis of 2008, there were several factors that prevented the financial sector from taking advantage of the opportunities of the digital revolution more keenly. On the one hand, the crisis resulted in a dynamic increase of the ratio of non-performing loans, which aggravated the capital positions of banks through impairment, and crisis management also soaked up significant human resources. On the other hand, the permanently low interest rate environment resulting from the crisis put the revenue side of banks under pressure, which could pose profitability challenges in the longer term with an unchanged cost level. Finally, the crisis also resulted in decreased trust by consumers in the banking system (Stevenson Wolfers 2011), and regulatory expectations also increased significantly. These factors combined posed significant challenges to banks and other financial operators in the restoration of their profit-generating capability.

By intensifying competition, technological innovations could fundamentally change the business models of active players of the financial sector, inducing risks into the system that must be addressed with active regulatory control under any circumstances. The role of the regulatory authority should be assessed in the geographical dimension, since each of the Hungarian, the European Union and the international set of rules comprises a different geopolitical system, and therefore in specific cases a substantial need for harmonisation arises in international technological companies. The operation of the large technological enterprises (BigTech) and that of the start-ups highly rely on digitisation, as well as on the various online platforms; therefore, these market actors are able to operate at a low cost level, and their activities may have a price-reducing effect. As a result, incumbent institutions ${ }^{1}$ should primarily adapt on the cost side (European Parliament 2017), since in their case high operating costs continue to pose a global problem (EY 2016).

The new technological solutions enable the actors in the financial sector to substantially improve their cost efficiency. In addition, the early adoption of new

\footnotetext{
${ }^{1}$ By incumbent institution we mean the regular financial institutions already present in the market.
} 
ideas could even secure a permanent competitive advantage, and furthermore, a solution that offers significant benefits in terms of the competitiveness of the economy could influence the behaviour of several external stakeholders. If the regulatory authority also recognises these benefits, the developments could also be supported by the targeted modification of the regulatory environment, which could further expand the opportunities of the first responders, maintaining their initial competitive advantage (Lee - Teo 2015). The exploitation of benefits deriving from early adoption is also important because on the business side it is favourable for the incumbent institutions that in developed countries a significant part of the consumers insist on their usual bank, which could enhance the cooperation between banks and FinTech companies on the one hand, while on the other hand, the existing significant customer base could support the identification and exploitation of future development opportunities (McKinsey 2016, FSB 2017). Additionally, the role of commercial banks in money creation and in the financial intermediary system also provides a significant competitive advantage compared to non-incumbent undertakings (MNB 2017).

In this study, we assess the regulatory tools that can be applied to encourage FinTech innovations, also focusing on aims of financial stability. First, we review the opportunities and potential threats brought about by these innovations from microprudential, macro-prudential and consumer protection aspects. Subsequently, we present the possible regulatory responses that could be provided to address the challenges generated by the FinTech phenomenon, and the regulatory tools applied in international practice. After that, in terms of legal implementation we provide a deeper analysis of the regulatory solutions, detailing their differences and similarities. Finally, we provide a brief presentation of the domestic regulatory initiatives encouraging FinTech innovations as well.

\section{The opportunities and threats of FinTech innovations}

In the relevant literature, we cannot yet find a completely uniform, commonly applied definition of the concept of FinTech (financial technology) concerning financial innovations that have become more and more common in recent years. In general, by these we mean the exploitation of innovative technology in the framework of financial services (Nicoletti 2017; MNB 2017). According to the report of the Financial Stability Board (FSB), FinTech is a technology-driven financial innovation which may result in new business models, applications or products that could have a meaningful effect on financial institutions, financial services and financial markets (FSB 2017; MNB 2017). Considering the fact that innovation has always been a characteristic feature of the financial sector, it is possible to identify several phases in the FinTech phenomena along technological development. The appearance of the first period goes back to the second half of the $1800 \mathrm{~s}$ with 
the appearance of the telegraph, and later on the telephone. The developments registered in the second half of the $20^{\text {th }}$ century and implemented as a result of the development of information technology can also be called FinTech 2.0 (e.g. ATM, telebank), while the rapid technological innovation seen in recent years is also mentioned in the literature as FinTech 3.0 (Arner et al. 2016).

The currently observable FinTech innovations can be assigned to the categories of efficiency innovation, sustaining technology and "disruptive technology" innovation (Christensen 1997). Efficiency innovations enhance an already existing technology: this category mainly includes solutions that build on existing infrastructure and improve its efficiency, whether these involve the expansion of payment opportunities, the optimization of account managing and administrative processes or the digitisation of back-office activities. Sustaining innovation is somewhat different, in which development is exclusively aimed at ensuring the viability of existing processes, for example, in cases when exogenous factors change. By contrast, disruptive technological innovations are capable of fundamentally changing existing business models. There are several solutions that are capable of providing financial services bypassing the regular financial service providers (e.g. P2P lending or insurance), or by automated data analysis and processing (e.g.: roboadvisory). From a regulatory perspective, it is primarily these latter innovations that merit special attention, since the market actors applying this kind of innovations are partially or fully outside the control of the regulatory and supervisory authorities, while they may have a significant influence on the entire financial intermediary system (MNB 2017).

Essentially, there is no technical impediment to FinTech innovations covering the entire value chain in terms of financial services, and therefore they may have a significant impact on the business models of incumbent institutions. The relevant solutions may be introduced at the level of a particular service type, but may also cover several financial functions and even become full substitutes for incumbent institutions (MNB 2017). From the funding side, in recent years investments in FinTech companies have increased significantly (with minor or major pauses), but significant differences can be registered globally. In fast-growing Asian countries with less deep financial intermediary systems and in North America an outstanding investment dynamic can be observed; by contrast, in Europe - including Hungary - activity is less intense (KPMG 2018).

In recent years, the efforts of both global and national regulatory authorities have substantially improved the resilience of the financial system to shocks. However, the appearance of new actors often applying disruptive technological innovations could have a meaningful impact not only on financial stability, but also on general cash demands, and through the structure of the financial system on monetary policy, or even on the framework of the central banks' lender of last resort function 
(Aaron et al. 2017). Therefore, the aim of the regulatory authorities could be the development of a regulatory framework that supports innovation occurring in the financial sector without jeopardising financial stability (MNB 2017). In the following section, we present the opportunities and risks related to these innovations.

\subsection{Possible positive impacts of technological innovations on financial intermediation}

In several segments of financial intermediation, FinTech innovations have the potential to improve the level of decentralisation and diversification of the system, which could mitigate the impact of future financial shocks. The advent of new products, services, business models and market actors as a result of the innovations could generate alternative fundraising and investment opportunities with a low level of correlation compared to other asset classes. The agent of new products and market actors could reduce market concentration, and even the number of systematically important institutions could decrease (FSB 2017).

The new products and services could facilitate financial integration, and financial intermediation could support economic development to a higher degree. Thanks to innovations, financial services can be made available to a wider community of consumers and investors (Nicoletti 2017; FSB 2017; EC 2017; Philippon 2016). This may be especially important for consumer groups and regions, where relations with financial service providers or a more developed financial infrastructure are currently only available to a limited extent.

FinTech innovations could induce meaningful efficiency improvement in the financial system (McKinsey 2016; FSB 2017; Nicoletti 2017):

- Rationalisation of back-office functions: Incumbent institutions could adapt several new technologies into their operations which could reduce the complexity and costs of back-office activities. Thanks to automated and algorithm-driven financial planning, statutory compliance could also become more efficient and cheaper (RegTech). ${ }^{2}$

- Optimisation of decision-making processes: The adaptation of machine learning and artificial intelligence could place the models applied by institutions and investors in decision preparation on new bases.

- Reduction of the branch network: On-line access to the services of the institutions and online administration create the opportunity to use most financial services on-line. As a result of the need for workload-decreasing offline processing, the branch networks of the individual service providers can be streamlined, and this process can be accelerated by the market entry of innovative actors.

\footnotetext{
${ }^{2}$ For more details on the concept of RegTech and SupTech, see: MNB (2017).
} 
- Reduction of searching costs: By the application of advanced Big Data-based methods of analysis and by comparative algorithms, it is possible to reduce searching costs, enabling more efficient decisions on capital allocation, both for institutions and consumers.

- Faster completion of transactions: Technological innovations could meaningfully accelerate the settlement times of transactions, which could reduce the interdependence of market actors. The risk-mitigating effect of more efficient settlement requires less tied-up capital and collateral, which enables more efficient capital allocation decisions to be made.

- Appearance of RegTech solutions: In order to ensure legal compliance, the institutions can apply innovative technological solutions. The regulatory encouragement of the application of technologies requires the management of new risks on the institutional side. However, the innovative tools of legal compliance are capable of substantially increasing the efficiency of the identification of risks and that of legal compliance itself.

- Use of SupTech innovations: Implementing digital, automated solutions to be applied in supervision can improve the efficiency of financial system's supervision. Aim of SupTech solutions, could be among others, is to strengthen the technological and IT angles of the audits, to establish granular data reporting and to develop automated supervisory mechanisms.

\subsection{Possible risks of technological innovations related to financial intermediation}

\subsubsection{Micro-prudential risks}

The rapid growth of FinTech actors could result in a significant increase in funding risks. In order to increase market share as soon as possible, the level of leverage may rise significantly for one actor - especially if its activity is unregulated - and the ratio of its disposable liquid assets could decrease. There is an increased risk of a substantial maturity mismatch developing between assets and liabilities, and in the case of lending activity, a significant interest rate risk may also arise. During a period of turbulence or as a result of temporary operating anomalies, these risks can materialise within a short time (FSB 2017; BIS 2018). The actors of the market could generate false initiatives for incumbent institutions. Because of the intensifying competitive situation, in an effort to maintain profitability, the risk appetite of these institutions could rise, thereby increasing the vulnerability of the financial system (BIS - FSB 2017).

Several operational risks could arise in relation to FinTech solutions. Naturally, operating risks could occur in the life of an enterprise: this could involve deficiencies of information systems, human errors as well as external interventions. However, 
in the case of FinTech innovations, in addition to these, matters of data quality and data protection, as well as cyber risks are also significant, additional risk factors (BIS 2018; FSB 2017):

- Data quality and data protection: The operation of FinTech innovations is fundamentally characterised by a high volume of shared data and their wide utilisation and analysis. As a result of data processing deficiencies, problems or deterioration in data quality, the automated processes and analyses could lead to incorrect results, meaning that there is the danger of errors committed by or deception of the customers or the customers losing money, and even unauthorised data utilisation could occur.

- Cyber risk: As a result of technological progress, the operation of market actors is based on sophisticated IT systems and software. Overview of these information systems may be complex and time-consuming, and it is difficult to determine if they are vulnerable, which creates the possibility of the development of systems exposed to both internal and external threats. The outsourcing of certain activities to third party providers could further reduce the transparency of operation, and any malfunction in the operations of these service providers could further increase the vulnerability of the business models of FinTech solutions.

\subsubsection{Macro-prudential risks}

The emergence of novel institutions and activities with systemic importance could pose a systemic risk. ${ }^{3}$ The market players which are the first adapters of a novel solution in financial intermediation may obtain a significant competitive advantage. This could result in the increase of concentration risks. If an actor which has become dominant in a narrower segment undergoes some kind of shock, substitutability could pose a problem because of the probably unique business model. With the spread of innovative technologies and solutions that determine and interconnect the operation of the individual actors, and not only institutions, even individual activities could become systematically important (BIS - FSB 2017).

The wide utilisation of FinTech innovations could also strengthen the procyclicality of the financial sector. The financial system, especially commercial bank lending is procyclical, since in the case of an economic upturn banks are prone to relax their lending conditions, while if there is a downturn in the economy, they may significantly restrain their lending activities, in an effort to stop the deterioration of profitability and of the capital position. As a result of the FinTech innovations, the procyclical operation of the financial sector could be strengthened: on the one hand, because of the automated decision-making of the market actors following similar

\footnotetext{
${ }^{3}$ It should be noted that as a result of the advent of FinTech innovators, the literature sees the possibility of both a decrease or an increase in the number of institutions with systemic importance.
} 
patterns, on the other hand, by way of the intensifying market competition (FSB 2017). The increased spread of FinTech innovations could even result in a situation where the financial system reacts with higher sensitivity to specific industry news, changes, and therefore volatility could increase substantially at systemic level.

The channels of contagion between sectors of the economy may increase. In the new business models, a direct interaction may develop between demand and supply, which increases the number of connection points between market actors, and the retail sector and enterprises could appear both as funders and investors. Since the main purpose of innovation efforts is typically the establishment of automated operation based on artificial intelligence, human supervision of the processes is also reduced, which could lead to the realisation of unexpected risks (FSB 2017). In several markets, the high level of connectedness among the incumbent institutions could persist, which may be supplemented by the interconnectedness of information systems. The increase of the number of connection points, the standardisation of information systems and interfaces, as well as the incorporation of the actors of the real economy into intermediation could mean several risk points for the entire financial system, and through the transmission channels the potential risks could spill-over into the rest of the sectors of the economy (Deutsche Bundesbank 2017).

\subsubsection{Impacts affecting customers}

It could pose a risk both from the consumer protection and the data protection side that certain innovative solutions require the financial service providers to use specific information for their application. The inappropriate handling of personal data or even their unauthorised use could deceive or harm consumers and investors. Consumer protection issues may also be of key importance in the case of crossborder, foreign transactions and services (BIS - FSB 2017).

\section{Table 1}

Opportunities and threats of FinTech innovations

\begin{tabular}{l|l|l}
\multicolumn{1}{c|}{ Area } & \multicolumn{1}{c|}{ Opportunity } & \multicolumn{1}{c}{ Threat } \\
\hline Micro-prudential & $\begin{array}{l}\text { Operational efficiency } \\
\text { of the market, lower } \\
\text { cost level }\end{array}$ & $\begin{array}{l}\text { Excessive risk-taking at individual level (leverage, } \\
\text { liquidity, maturity mismatch), appearance of } \\
\text { unsustainable business models, mounting operating } \\
\text { risks (data quality, cyber risks) }\end{array}$ \\
\hline Macro-prudential & $\begin{array}{l}\text { Diversification, } \\
\text { decentralisation }\end{array}$ & $\begin{array}{l}\text { Intensifying procyclicality (with effects that could } \\
\text { even spill-over to other sectors), appearance of new } \\
\text { institutions and services with systemic significance, } \\
\text { intensifying opportunity of regulatory arbitrage }\end{array}$ \\
\hline $\begin{array}{l}\text { Impacts affecting } \\
\text { customers (consumer } \\
\text { protection, data } \\
\text { protection) }\end{array}$ & $\begin{array}{l}\text { Increasing level of } \\
\text { financial integration, } \\
\text { decreasing searching } \\
\text { costs, new products, } \\
\text { services }\end{array}$ & $\begin{array}{l}\text { Challenges of customer protection, data protection } \\
\text { risks }\end{array}$ \\
\hline
\end{tabular}

Source: Based on BIS (2018), FSB (2017) and MNB (2017) 


\section{Potential regulatory responses to challenges posed by FinTech}

\subsection{Regulatory dilemma concerning FinTech solutions}

With regard to FinTech solutions, the regulatory dilemma basically lies in finding the balance between the "laissez-faire" approach and an entirely prohibitive regulatory approach (Figure 1). The establishment of the optimal framework is based on the assurance of equal competitive conditions. It is also important to encourage the actors to consider the systemic risks as well in their own operation, in addition to the individual risks (He et al. 2017). The restricted availability of the expertise necessary for the new technologies may make the development of the regulatory framework more difficult. In addition, the technological innovations that appeared in the FinTech industry are characterised by a high level of heterogeneity already, and in the future we should anticipate the emergence of an even more complex market (MNB 2017).

\section{Figure 1 \\ Regulatory dilemma concerning FinTech solutions}

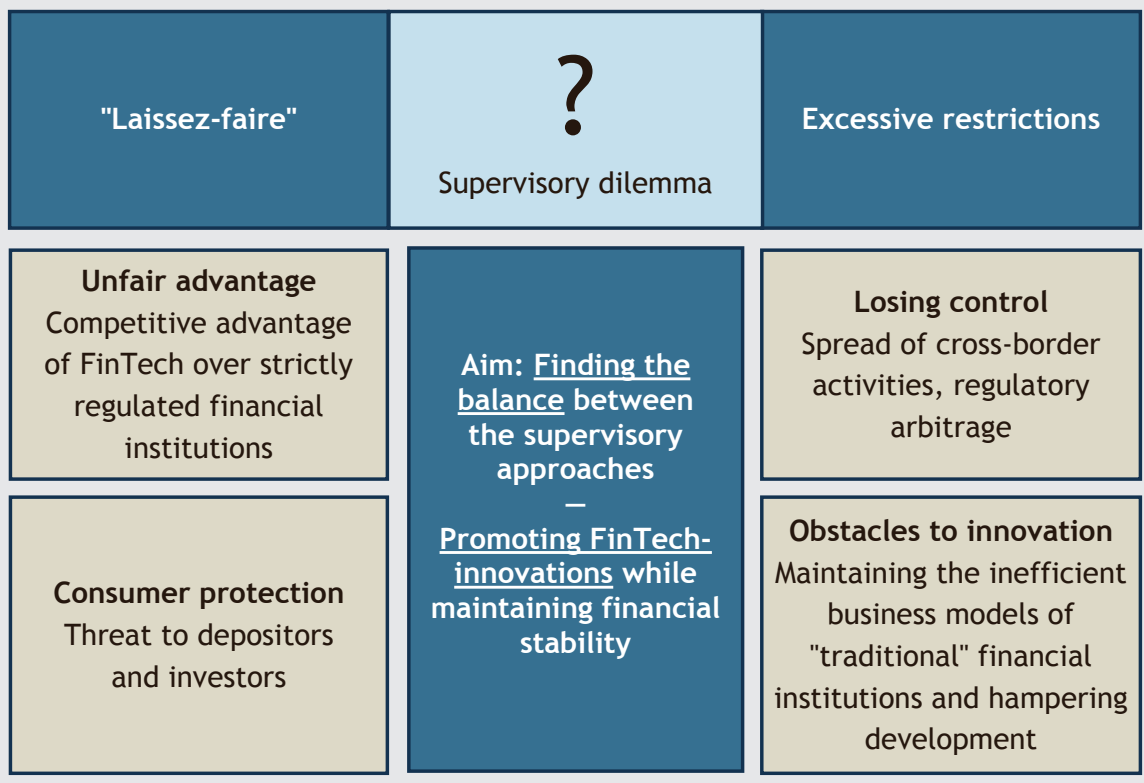

Source: MNB (2017)

An exceedingly permissive regulatory approach could - through the intensifying competition - reduce the price of services, but at the same time, from the aspect of consumer protection such an approach involves several risks. FinTech institutions would enjoy an unjustified competitive advantage compared to the severe regulatory requirements which apply to financial actors. The lack of rules 
entails risks for all of the affected parties as well. For example, a solution that is not mature enough could cause unexpected losses both to consumers and funders. It could pose a further risk that financial intermediation could shift into a segment over which the regulatory authorities only have indirect control. As a result, new market actors with less experience would also not be able to develop an efficient risk management mechanism (Zetzsche et al. 2017; MNB 2017).

At the same time, the total prohibition of FinTech solutions could hinder innovations. In addition to hampering innovation, in an excessively stringent regulatory environment both innovations and customers could leave the domestic market. The exploitation of cross-border opportunities would probably further increase the costs of regular financial services, since the domestic actors would offset the departure of new consumers who prefer foreign opportunities by higher prices (WEF 2016). The lack of new entrants and the lack of competition has been a major problem of the domestic financial sector for the past decades, since financial services continue to be expensive in Hungary and so far the innovations have not delivered significant benefits for consumers (Nagy - Vonnák 2014).

As a response to the emerging financial innovations, the most important task of the regulatory authority may be to find a balance, which - in addition to ensuring the guarantees for consumer protection and required under competition law in respect of FinTech solutions - does not function as a hindrance to innovation. Overall, it may have a meaningful effect on the long-term performance and competitiveness of the economy, how a given regulatory system addresses the advent of FinTech innovations and how it can appropriately encourage their spread, while addressing the risks efficiently (MNB 2017). The application of the so-called Innovation Hub and Regulatory Sandbox regulatory concepts could provide a solution for finding that balance. ${ }^{4}$

Typically, new technologies have a significant potential in the long term in the individual sectors of the economy, but various phases can be identified in their evolution and wide spread. The so-called hype cycle provides an overview of how a new technology and its application evolve over time (Gartner 2017). Five phases can be identified in the cycle: the emergence of innovation, the peak of inflated market expectations caused by increasing market interests, the trough of disillusionment caused by the temporary loss of trust, the process of "enlightenment" laying the basis for sustainable development, and the actual emergence of value-creating processes arising from the innovative technology, i.e. the long-term improvement of productivity (see Figure 2).

\footnotetext{
${ }^{4}$ In the domestic literature, no widely accepted translation has been developed for these concepts as yet, and therefore in the study we basically use the English terms. The MNB uses the English terms as well as the Hungarian terms of "Pénzügyi Innovációs Platform" and "Pénzügyi Innovációs Tesztkörnyezet".
} 


\section{Figure 2}

The hype cycle as a variable of time and expectations

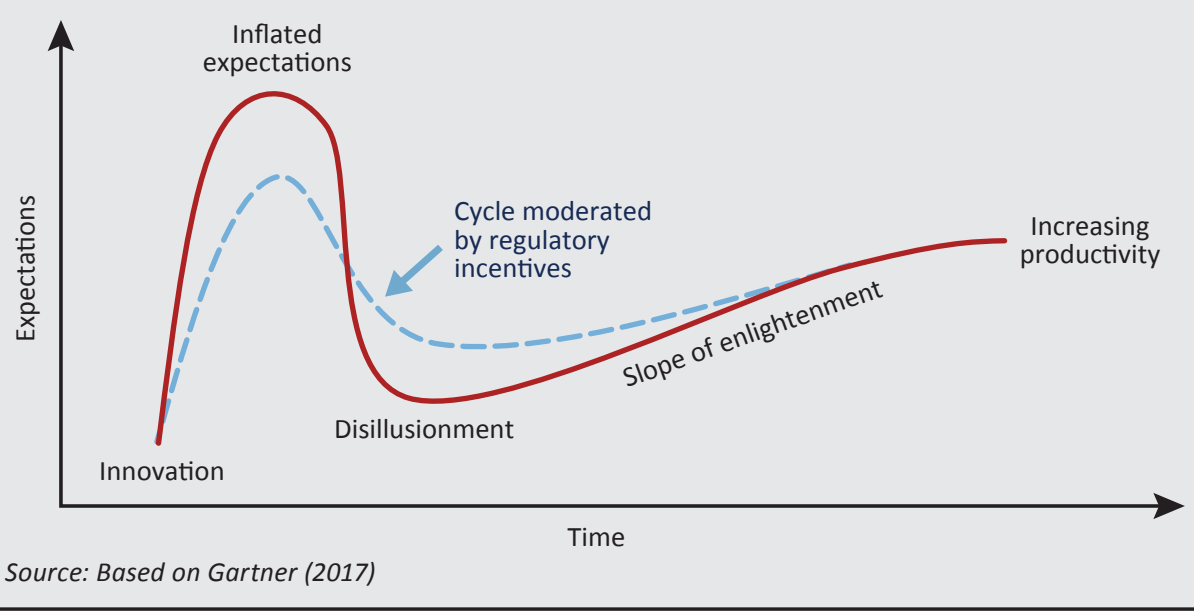

A supportive regulatory approach, for example, the application of an Innovation Hub or a Regulatory Sandbox, could exert a favourable impact by mitigating the swings caused by inflated expectations. On the one hand, it is possible to improve the sophistication of business models by the appropriate regulatory tools, and consequently products or services which will probably represent substantial added value could enter the market even at an early stage of development. On the other hand, in parallel, market failures can also be moderate, therefore the impact of the loss of trust through disillusionment could also be less powerful.

\subsection{The Innovation Hub as a supporting regulatory tool}

The Innovation Hub is a platform provided by the regulatory authority, where FinTech innovators can receive guidance from the authority. Within this framework, the experts of the regulatory authority answer the questions received from the representatives of FinTech innovations and provide assistance in interpreting the legal requirements; they also survey the needs for changes to legislation and forward such to the decisionmakers (thereby probably also making the general regulatory environment more favourable for innovations). This institution is available for both unregulated and currently regulated activities; furthermore, both the innovations of newly established enterprises and the new technological solutions of incumbents (e.g.: banks, insurers) could be covered by it.

The scope of activities of the Innovation Hub could cover a broad spectrum. In the default case, Innovation Hubs were established mainly for addressing FinTechspecific questions on banking services, but in response to increasing market demands, questions for guidance may typically involve additional segments of the system of financial intermediation, for example, by the involvement of the InsurTech 
or RegTech areas. In addition to guidance in relation to direct queries, several hubs also provide an opportunity for the constant maintenance of connections, in which the authorities also provide assistance with obtaining licenses. The operators of the hub monitor and support newly established enterprises for a specific period of time, typically for 12 months following the date of obtaining the license.

It is an advantage of the Innovation Hub that the innovators can ask their specific questions on a dedicated channel, which enhances the speed of the process of responding. It is another feature that questions are subject to preliminary screening. The purpose of this criterion is to ensure that the innovators receive appropriate information before asking their questions on their opportunities and expected obligations. Usually, innovators need to assess the market availability of their idea based on some questions, as well as the novelty contents and expected impacts thereof on the potentially affected parties and on the economy of the given country (MNB 2017).

\subsection{The concept of the Regulatory Sandbox}

The Regulatory Sandbox enables innovators to assess the viability of their financial product, business model in a "test environment" controlled by the regulatory authority, while enjoying exemption from certain regulatory obligations for a specific period of time. The tests are carried out with the involvement of real consumers. It is a common feature of every Sandbox that they allow the testing of the innovation under real market circumstances for a specific time only - typically for 6 to 12 months - and only involving a predefined number of customers. During that time, the regulatory authority waives compliance with certain predefined regulatory requirements. Typically, it is an essential condition for getting into the test that the innovation should have a significant content of novelty for the consumers or the clients, and that the party applying the innovation should generally comply with the requirements of market entry. If the service proves to be viable in testing, then actual market entry can take place.

Depending on country providing the legislative environment for the implementation of the concept and on the conditions applied by that legislation to allow the operation of the concept, every Sandbox has a toolset that ensures legal application. In certain cases the supervisory authority may issue a statement of intent on the restriction of supervisory actions ("no enforcement action letters" - NAL), which remains valid as long as the time of compliance with the testing conditions and may also provide individual guidance to the tester, in order to ensure compliance with the legal environment. It is also possible to grant a restricted, temporary operating license to companies with no license from the supervisory authority. In such cases the application for the operating license may be assessed faster, and the obligations imposed by the regulatory authorities may also be more moderate in these initial phases (MNB 2017). 


\section{International initiatives}

More and more countries recognise that the FinTech phenomenon requires an appropriate regulatory response. At the same time, the national supervisory practice supporting innovation is not consistent. Dedicated frameworks encouraging the spread of FinTech innovations have been established only in a few countries so far. The most typical situation is when the supervisory authority takes individual steps. With these steps, market actors can usually gain more detailed knowledge of the legislative framework applying in the given country - especially the obligations strictly attached to their product or service under development - in more detail and furthermore they can receive support in the form of consultation during the process of obtaining their activity license. So far, Innovation Hubs have only been established in a few countries, at present less than 20 such dedicated frameworks are operated globally ${ }^{5}$ (BIS 2018). Figure 3 summarises the European presence of such Hubs.

\section{Figure 3 \\ Innovation Hubs and other solutions of supervisory authority supporting innovation in Europe}

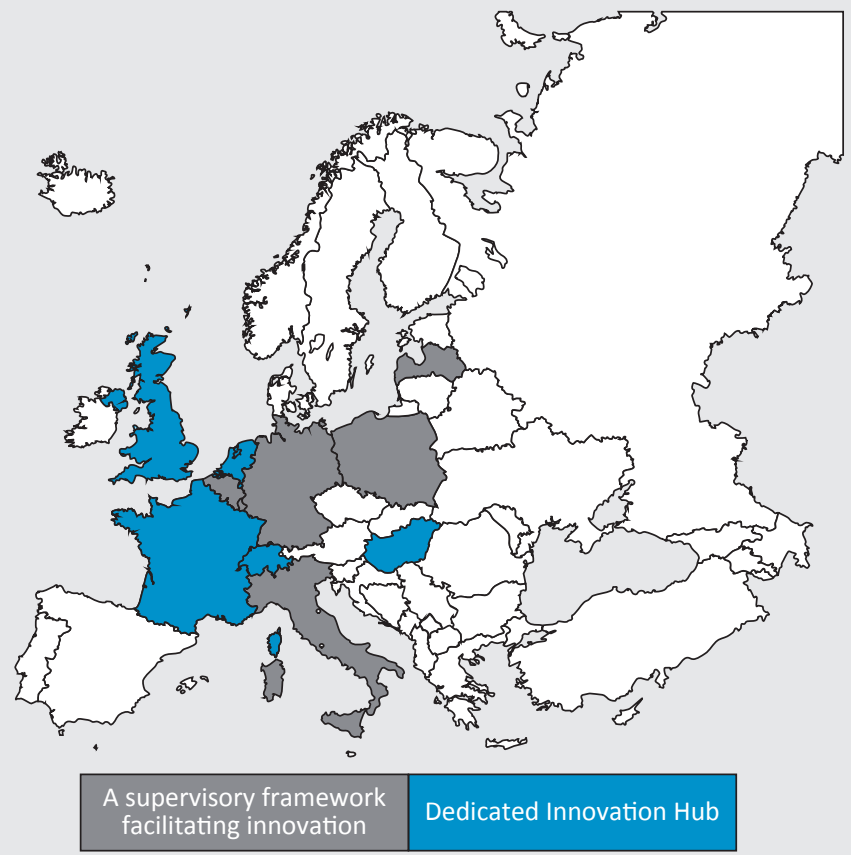

Source: Based on BIS (2018)

\footnotetext{
${ }^{5}$ We note that there are several institutions around the world called Innovation Hubs, but the study only allocates those to this category for which a thorough assessment of their functions and activities so far reveals that they provide comprehensive services to FinTech innovators.
} 
At present, the framework of Regulatory Sandbox is not widely applied yet (see Figure 4). Since the first application in the United Kingdom, the number of actually operating Sandboxes is less than ten and they are typically applied in Asia. Other than the remarkable case of Great Britain, at present in Europe only the Netherlands and Switzerland are operating dedicated Regulatory Sandboxes. In the Netherlands, based on the publicly available information, no testing has been performed so far. In the case of Switzerland, the Sandbox primarily functions as a testing environment with limited application: it enables the collection of deposits without a banking license, in an amount not exceeding 1 million Swiss francs. Lithuania started an official consultation on the introduction of the Sandbox in the summer of 2017.

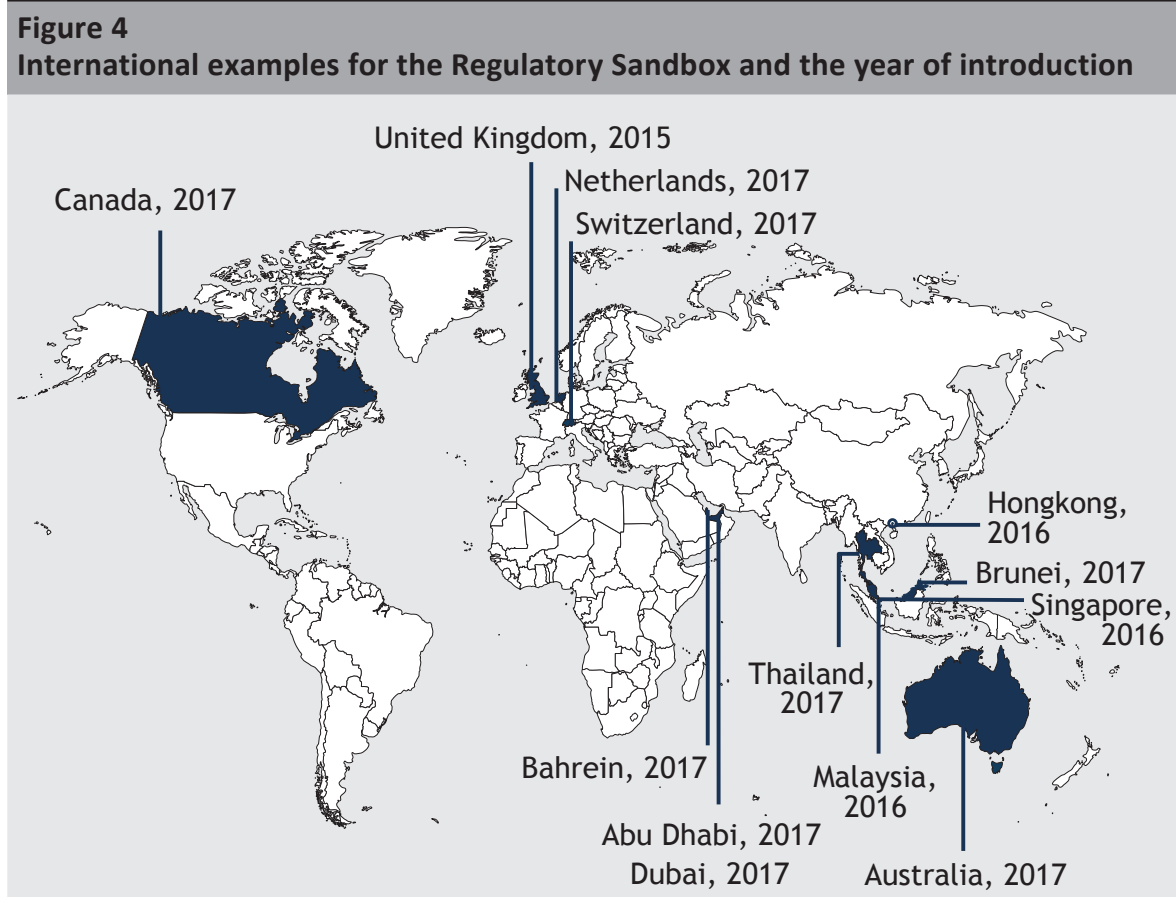

Note: In the figure we have indicated the situation at the end of 2017.

Source: BIS (2018), MNB (2017)

At the European Union level, more initiatives are evolving for the development of coordinated responses to the FinTech phenomenon. In 2016, the European Commission set up a working group for the establishment of the relevant regulation. Its task is to review the existing rules to ensure that they meet the challenges of the digital age. The FinTech Action plan of the EU was published in 2018, based on this work (EC 2018). The European Banking Authority has also developed its schedule for the period of 2018/2019, in which the results of their 2017 market consultation were also taken into account (EBA 2018). On the one hand, the European Central Bank (ECB) has launched public consultation concerning the conditions of the 
operation of banks applying the new type, FinTech business model, since they are receiving an increasing number of applications for operating licenses in parallel with the spread of FinTech solutions (ECB 2017a). In March 2017, ECB also issued a communication in which the establishment of a FinTech Hub covering the euro area is indicated as an objective. The purpose of the future platform uniformly available for the 19 countries would be to facilitate the exchange of information and the sharing of international good practices (ECB 2017b).

\section{Seeking the optimal regulatory response: characteristics of the individual Regulatory Sandboxes}

Considering the fact that Regulatory Sandbox frameworks are special legal schemes, it should be assessed what codification solutions are applied by the individual countries for running the testing environment. Accordingly, in the following section we will review the practices applied for the best-known Regulatory Sandboxes, detailing the solutions observed in the Asian, the Anglo-Saxon and the European Continental legislative systems. Given the fact that the general attributes of the sandbox-phenomenon were summarized as mentioned above in this chapter the specificities will be covered primarily.

\subsection{The international practice of Regulatory Sandboxes}

Although the individual frameworks serve the same purpose, in respect of actual implementation several peculiarities can be identified in the case of the individual countries: 6

- Singapore: One characteristic feature of the framework developed by the Monetary Authority of Singapore (MAS) in 2016 is that the testing period can be extended if the tester proves that it needs additional time to ensure compliance with the entire legislative environment, or if during testing it has changed the originally tested service in the meantime because of consumer feedback (MAS 2016). In addition to time extension, the framework also enables the extension of the testing parameters. However, if testing can be expected to be unsuccessful, the testing period can be terminated. ${ }^{7}$

\footnotetext{
${ }^{6}$ As indicated earlier, in Switzerland, Canada and several other, typically Asian countries there are also Regulatory Sandboxes in operation, but for these countries at present no appropriate comparison can be made owing to the peculiarities of the legislative systems and the scarcity of available information.

${ }^{7}$ The guidance of the Singaporean authority provides a list of cases when decision is made on the closing of the testing period, these are the following:

a) MAS is not satisfied that the sandbox has achieved its intended purpose, based on the latest test scenarios;

b) the sandbox entity is unable to fully comply with the relevant legal and regulatory requirements at the end of the sandbox period;

c) a flaw has been discovered in the financial service under experimentation where the risks posed to customers or the financial system outweigh the benefits of the financial service under experimentation;

d) the sandbox entity breaches any condition imposed for the duration of the sandbox;

e) by the decision of the sandbox entity.
} 
- Malaysia: The Malaysian system shows the image of a fully flexible approach. This can be considered, among others, from the fact that even such basic attributes as the limited number of consumers or the time dimension of the testing opportunities are treated flexibly, and exceptions can be made from these - at least in theory, at the level of the regulatory system (BNM 2016).

- Australia: One attribute of the system operated by the Australian securities regulatory authority (ASIC - Australian Securities \& Investments Commission) since December 2016 is that it grants exemptions not only on the basis of the application of individual legal entities, but - if the Australian legal conditions apply - also concerning the performance of activities belonging to predefined activity classes, regardless of the person who performs the activity. It is a further characteristic feature of the system that if certain special conditions are met, in respect of the future consequences of non-compliance in the past, the authority provides the opportunity of giving a retroactive exemption as well.

- United Kingdom: The Financial Conduct Authority (FCA), which acts as the British financial supervisory authority, makes available a broad set of potentially applicable tools in the Sandbox, such as a dedicated supervisory statement that excludes legal enforcement, the procedure aimed at obtaining a limited license, and the exemption procedure (FCA 2015a). Of the items listed above, the procedure aimed at obtaining a limited license should be highlighted. As a result of the license, a flexible, dynamically changing regulatory framework mechanism will be established for the testing entity: in every stage of testing the testing entity only needs to comply with those expectations that are in proportion with the tested activity at the given moment in time, according to the constant assessment of FCA. They ensure the establishment of a system of equal conditions among the individual testers performing similar activities by group testing periods (cohorts). Accordingly, in contrast with the rest of the Sandboxes, the period of application for the testing environment is not continuous, it is only possible in certain specified time intervals. It should also be mentioned that only enterprises may enter the Sandbox for which FCA has checked individually whether the consumers have received appropriate information concerning the service, and whether they have received appropriate protection, and within that, the right of sufficient indemnification.

- The Netherlands: The Dutch concept does not cover the sphere of obligatory statutes, for reasons that include the application of Union regulations, most of which cannot be amended on national authority. In accordance with that, the Dutch framework focuses on the technological features of the innovative solution, and on ensuring that their favourable impact is felt concerning the stability and efficiency of the financial system and the security of consumers (DNB 2016). Therefore it can be primarily considered a facilitating framework, in which "soft" regulatory requirements play the main role. 


\subsection{Legal attributes of the Regulatory Sandboxes}

Regulatory Sandboxes show dissimilarities in terms of legal implementation as well. The differences can be analysed in three areas. The first is to review the legislative changes necessitated by the introduction of the legal institution, or whether it is supported by a legislative base at all, or if it only involves the suspension of the toolset applying to their enforcement. The second criterion to be assessed is the subject of application, i.e. the obligations from which exemption can be granted in the framework of the Sandbox. Finally, the issue of the identity of the persons to whom the established concepts will apply should also be assessed (Table 2).

\subsubsection{Legislative burden and scope of application in relation to the development of the concept}

In respect of the legislative burden and the closely related scope of application, very significant differences can be observed regarding the concepts under examination. If we assess the Asian Sandboxes, based on the limited information we have available, we can conclude that the legal basis of the exemption (making testing available) is an act belonging to the legislative powers of the supervisory authority. The fact that in the framework of the Sandboxes exemptions can be granted only from certain legal and regulatory requirements imposed by the supervisory authority gives rise this conclusion. These requirements may include, in addition to the legislation issued by the authority per definitionem, waiving the application of the acts otherwise expected by them that have no legal binding effect (soft law), and the requirements enabled by the discretionary latitude guaranteed by statutes for the authority.

The Australian concept clearly goes beyond the scope presented above, since ASIC has a legally defined discretionary power to grant exemption ${ }^{8}$ from the expectations of a set of individually defined regulations. In addition to the explicit exemption system, the Australian model includes a significant efficiency increasing tool on one more point. If any of the provisions contained in the statutes listed above is unclear or cannot be clearly interpreted as applying to a particular innovation, then within its own discretion ASIC may grant an exemption from compliance with these as well, subject to the procedural and other rules of the Sandbox concept ${ }^{9}$ (ASIC 2009).

Despite a legislative system that is similar to that of Australia, FCA applied a fundamentally different codification solution when developing the concept. The law laying down the fundamental rules of the provision of financial services in Britain states that FCA may grant an activity license to any entity if it complies with the necessary conditions, unless FCA releases the entity from the need to comply with these requirements (FCA 2015b). Therefore, FCA may provide during the licensing procedure already that certain applicants that apply innovative solutions do not

\footnotetext{
${ }^{8}$ Corporations Act 2001 (Corporations Act); Superannuation Industry (Supervision) Act 1933 (SIS Act); National Consumer Credit Protection Act 2009 (National Credit Act); National Consumer Credit Protection (Transitional and Consequential Provisions) Act 2009 (Transitional Act).

${ }^{9}$ So-called comfort relief
} 
have to comply with certain licensing criteria, or they are subject to more lenient conditions of compliance.

The Dutch system has not resulted in a legislative burden, but this also means that efficiency can apply within a relatively narrow scope. The authority may not extend the scope of application of the Sandbox beyond the "soft law" and its own discretionary powers defined in legislation. Although to a decreasing extent, the power of exemption may also apply to non-binding regulatory acts of European supervisory institutions (e.g.: EBA, ESMA) (DNB 2017).

\subsubsection{The personal scope of the concepts}

Personal scope means what are the legal entities which have a potential opportunity to test their services in a Sandbox framework in the given country. In many cases, the Sandbox concepts provide a wide scope of possibilities for the potential inclusion of undertakings with no activity license in the group of testers.

The Asian solutions under examination treat the scope of applicants flexibly. According to the concepts developed by MAS, in addition to obviously enabling the applications of entities licensed to provide financial services, enterprises can compete with them that do not hold an activity license at the moment, but are likely to obtain one. Malaysia also opted for a similar solution. On the one hand, the National Bank of Malaysia (Bank Negara Malaysia - BNM) enables entry into the Sandbox for financial entities holding an activity license issued by it. However, this rule can be loosely interpreted, inasmuch as other innovation providers are also allowed to apply for inclusion together with the financial entity. On the other hand, it is also possible for such undertakings to apply for participation that only plan to obtain the license for operating as a financial entity (BNM 2016).

The concepts operating in the Anglo-Saxon legal systems also support the above approach, but in certain cases entities without a license are subject to a preliminary screening with exhaustive conditions. ASIC will accept the application of nonlicensed entities subject to compliance with each of a set of conditions (ASIC 2017). However, these conditions are not only attached to this capacity of the entity performing non-license-bound activities, but also cover the entire scope of eligibility criteria. The United Kingdom establishes three different categories, enabling the entities covered by these categories to apply. On the one hand, the Sandbox of FCA is naturally open to entities with an activity license, on the other hand, it is also open to those that launched the procedure for obtaining the activity license. Thirdly, regardless of the activity license, FCA allows entry for all undertakings whose activity can be related to some kind of technological innovation.

At present, the Union legislation does not allow the performance of financial activities without a license, and there are no exceptions. Accordingly, the Netherlands also represents the most conservative position concerning personal 
scope, in that it only allows financial entities to apply for the Sandbox (DNB 2016). The procedure on the activity license of financial entities intending to settle in the member states of the banking union is conducted by the European Central Bank $(E C B)$, subject to the rules on the standard supervisory mechanism, regardless of the size of the entity. In the procedure, the ECB is required to apply not only the relevant directly applicable Union statutes, but also the legislation of the member states that transposed the Union Directives. Since these are minimum harmonisation provisions, the legislation of the member states may also impose more stringent requirements. In this latter case, the ECB is also required - despite its quality as an institution of the Union - to apply the purely member state level legislation imposed for the licensing requirements. However, since the Union rules do not contain any exemption opportunities that may be granted in case of the application of financial innovations, the legislation of the member states also cannot impose any such measures. However, such an exemption is possible while observing the currently applicable Union rules, which would only allow departures in the framework of a Sandbox type legal entity from those requirements of the member states that are defined more strictly than the requirements of the Union.

\begin{tabular}{|c|c|c|c|c|}
\hline $\begin{array}{l}\text { Table } 2 \\
\text { Compara } \\
\text { accordin }\end{array}$ & $\begin{array}{l}\text { e presen } \\
\text { o three c }\end{array}$ & $\begin{array}{l}\text { tation of the Regula } \\
\text { osen criteria }\end{array}$ & Sandboxes under & xamination \\
\hline Region & Country & $\begin{array}{l}\text { Legislative } \\
\text { burden/technique }\end{array}$ & Scope & Personal scope \\
\hline \multirow[t]{2}{*}{ Asia } & Singapore & $\begin{array}{l}\text { Presumably an act } \\
\text { within the legislative } \\
\text { powers of MAS }\end{array}$ & $\begin{array}{l}\text { - Legal and regulatory } \\
\text { requirements imposed } \\
\text { by MAS }\end{array}$ & $\begin{array}{l}\text { - Financial institutions } \\
\text { - Entities likely to obtain } \\
\text { the license }\end{array}$ \\
\hline & Malaysia & $\begin{array}{l}\text { Presumably an act } \\
\text { within the legislative } \\
\text { powers of BNM }\end{array}$ & $\begin{array}{l}\text { - Legal and regulatory } \\
\text { requirements imposed } \\
\text { by BNM }\end{array}$ & $\begin{array}{l}\text { - Financial institutions } \\
\text { - Licensed entities and } \\
\text { FinTech enterprises } \\
\text { together }\end{array}$ \\
\hline \multirow[t]{2}{*}{$\begin{array}{l}\text { Anglo- } \\
\text { Saxon } \\
\text { countries }\end{array}$} & Australia & $\begin{array}{l}\text { - Economic law } \\
\text { - Supervisory law } \\
\text { - Law on consumer } \\
\text { credit }\end{array}$ & $\begin{array}{l}\text { - Legal provisions in } \\
\text { three relevant laws } \\
\text { - In the case of rules } \\
\text { that cannot be clearly } \\
\text { interpreted, it is } \\
\text { "comfort relief" }\end{array}$ & $\begin{array}{l}\text { - Financial institutions } \\
\text { - Entities meeting the } \\
\text { conditions defined by } \\
\text { ASIC and having no } \\
\text { license }\end{array}$ \\
\hline & $\begin{array}{l}\text { United } \\
\text { Kingdom }\end{array}$ & $\begin{array}{l}\text { - The Financial Services } \\
\text { and Markets Act }\end{array}$ & $\begin{array}{l}\text { - Discretionary right of } \\
\text { the FCA }\end{array}$ & $\begin{array}{l}\text { - Financial institutions } \\
\text { - Entities that officially } \\
\text { applied for a license } \\
\text { - Innovative unlicensed } \\
\text { entities }\end{array}$ \\
\hline Euro area & Netherlands & $\begin{array}{l}\text { - No legislative burden } \\
\text { has emerged }\end{array}$ & $\begin{array}{l}\text { - National level and } \\
\text { Union "soft law" } \\
\text { - Discretionary powers } \\
\text { of the authority } \\
\text { defined by statute }\end{array}$ & - Financial institutions \\
\hline
\end{tabular}




\section{Domestic initiatives concerning FinTech innovations}

The establishment of an appropriate regulatory framework applying to the FinTech industry is of outstanding importance for the national economy and for the competitiveness of the financial system. With the exploitation of FinTech innovations, in the longer term cost efficiency improvement can be accomplished in the financial sector, and the customised regulatory responses contribute to the strengthening of stability and to the potential increase of the consumer surplus. Indirectly, how Hungary manages the appearance of FinTech innovations could also influence the long-term performance and competitiveness of the Hungarian economy. For the time being, the FinTech investment activity of the East-Central European region is low by international standards, which could be significantly improved by the establishment of a supporting regulatory framework.

In the Hungarian system of financial intermediation a significant need has been registered, both on the demand and the supply sides, for the secure application of innovative financial services. Considering the consumer side, there is already a significant group in the population in Hungary - comprising about 15 to 20 per cent, according to the Residential survey of the MNB - which is interested in the innovations provided by FinTech. Projected on the active population, this means that about 1 million consumers can already generate potential demand for novel solutions. The level of rejection is lower in the case of the younger generations, and therefore in the future the overall residential openness may continue to increase (MNB 2017). On the part of the domestic industry actors - the incumbent institutions and the newly established FinTech companies - there is also substantial interest in the application of FinTech innovations. Several institutions have relevant plans, and many of them are already using innovative solutions, primarily related to mobile and digital payment solutions, and payment initiation services (MNB 2017).

After mapping the international practice and surveying the opinions of Hungarian stakeholders, the MNB Innovation Hub (Financial Innovation Platform) started operating in March 2018, with the mission of supporting Hungarian financial innovations. ${ }^{10}$ The first step taken by the MNB aimed at the encouragement of FinTech innovations within a secure framework was the establishment of an Innovation Hub. The MNB Innovation Hub applies four functions to enhance the feasibility of innovative ideas. The Information repository enables the initiators of innovations to obtain an appropriate volume of high-quality information in a systematic form concerning the applicable legislative expectations and obligations. The Regulatory supporting platform provides an opportunity for the clarification of legal issues raised concerning innovations by obtaining the guidance of the MNB. The Communication hub provides an information-sharing interface for the entire FinTech

\footnotetext{
${ }^{10} \mathrm{https}: / /$ www.mnb.hu/en/innovation-hub
} 
ecosystem. The Innovation Hub also functions as an international cooperation platform. This function serves the establishment of connections with foreign regulatory authorities that are in the vanguard in the support of FinTech innovations.

According to international experiences, the establishment of a Regulatory Sandbox framework is an important element in facilitating the sphere of financial innovation. The MNB is already studying the opportunity of the establishment of a Regulatory Sandbox, in coordination with the relevant domestic institutions and other stakeholders. Based on their feedback, a significant number of market actors would participate in a dedicated testing environment (Figure 5), and several potential applicants have already identified the service that they would like to test there. ${ }^{11}$

\section{Figure 5 \\ Opinions of the market actors (banks, insurers, funds, intermediaries and FinTech companies) on the establishment of a domestic Regulatory Sandbox}

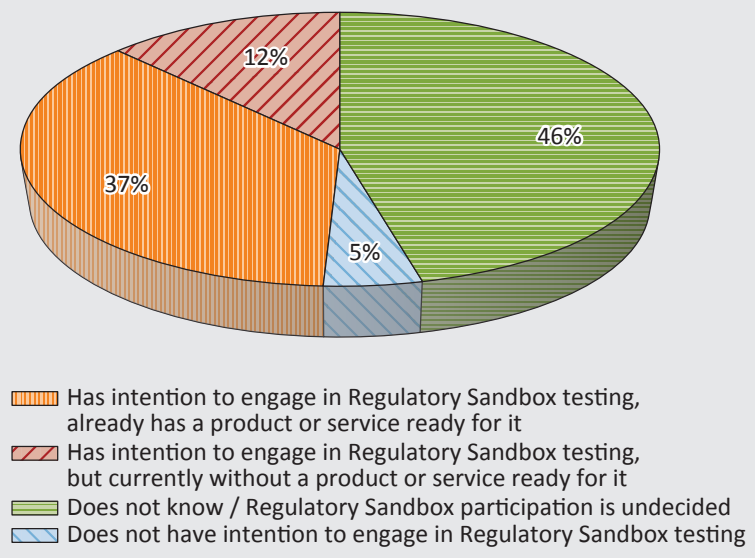

Note: Based on the responses of 83 market actors.

Source: MNB

Over the longer term, FinTech innovations could induce changes at each level of the legislative hierarchy (Figure 6), as solutions are being developed the legal background of which is often far from being settled at present. In other cases, the difficulties are caused by the legal framework or expectations of the law enforcing authority which are often unclear or are not easy to interpret for the novel solutions. According to the feedback of market actors, the Innovation Hub and the Regulatory Sandbox could provide a solution concerning most of the presently occurring legal problems for the clarification of the legal framework of innovative

${ }^{11}$ See the relevant Consultation document of the MNB on the methodology of the survey and on its further results: MNB 2017 
solutions. However, issues may also arise that could only be fully settled through national or even EU-level legislation. The regulatory solutions created and intended to be introduced by the MNB could also support this legislative process by collecting and making available daily updated information and by constant communication with the affected actors.
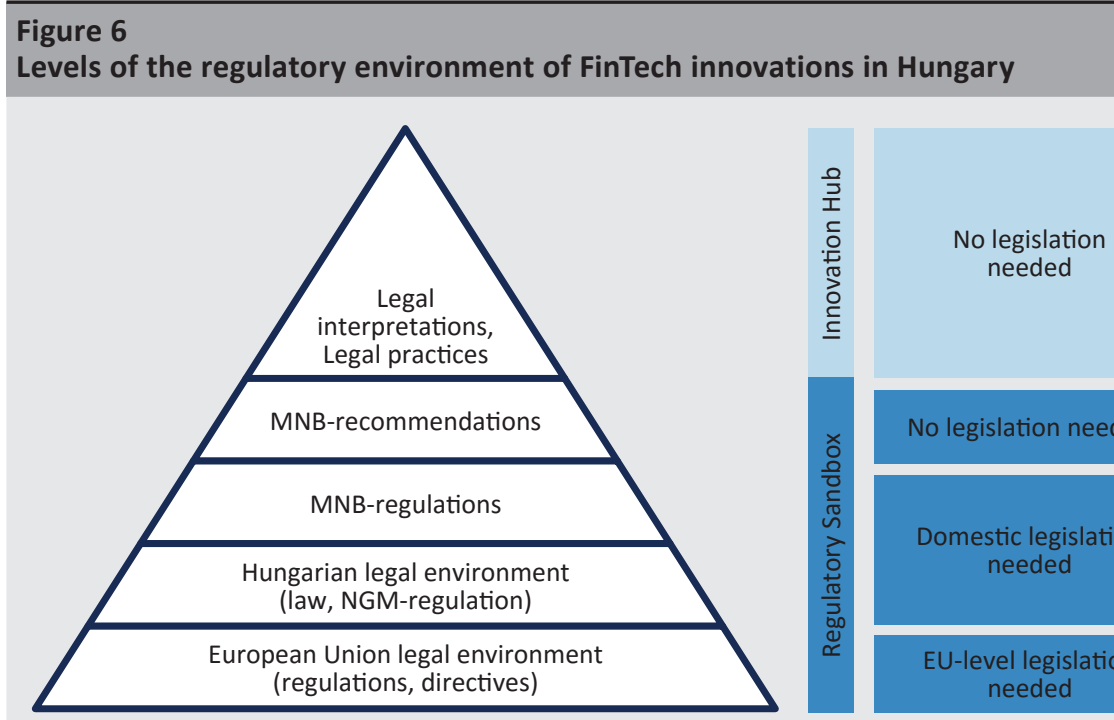

Note: NGM is the Ministry for National Economy in Hungary.

Source: MNB (2017)

\section{Conclusion}

The process of consulting with the significant actors in the domestic FinTech ecosystem and the consideration of international best practices both indicate that the most efficient tools of finding the optimal regulatory approach concerning FinTech innovations are probably the Innovation Hub and the Regulatory Sandbox (MNB 2017). These concepts are suitable for exploring which innovative idea carries what kind of market potential, without creating complicated regulations imposing a significant legislative burden "in advance". If an innovation proves to be durable and offer a significant customer benefit, then after the application of the concepts, the regulatory authority can start the implementation of the relevant legal framework in possession of the appropriate amount of information.

At the same time, an assessment of the international cases has also revealed that there is no generally effective, standardised solution that meets every geopolitical requirement: when the concepts are developed, the special features of the financial intermediary system of the given country, the level of financial culture and the specific solutions of the applicable legal framework must also be taken into account. 
Therefore, the simple "imitation" of solutions that function efficiently abroad is not viable, and we can expect a mixture of international best practices and local characteristics to provide an efficient concept.

\section{References}

Aaron, M. - Rivadeneyra, F. - Sohal, S. (2017): Fintech: Is This Time Different? A Framework for Assessing Risks and Opportunities for Central Banks. Bank of Canada Staff Discussion Paper, 10.

Arner, D.W. - Barberis, J.N. - Buckley, R.P. (2016): The evolution of FinTech: A new post-crisis paradigm? UNSW Law Research Paper, No. 62.

ASIC (2009): Applications for relief. Regulatory Guide 51. http://download.asic.gov.au/ media/1238972/rg51.pdf. Downloaded: 27 February 2018.

ASIC (2017): Testing fintech products and services without holding an AFS or credit licence. http://download.asic.gov.au/media/4420907/rg257-published-23-august-2017.pdf. Downloaded: 27 February 2018.

BIS - FSB (2017): FinTech credit, market structure, business models and financial stability implications. http://www.bis.org/publ/cgfs_fsb1.pdf. Downloaded: 10 February 2018

BIS (2018): Sound Practices, Implications of fintech developments for banks and bank supervisors. Basel Committee on Banking Supervision, February. https://www.bis.org/ bcbs/publ/d431.htm. Downloaded: 10 March 2018.

BNM (2016): Financial Technology Regulatory Sandbox Framework. http://www.bnm.gov.my/ index.php?ch=57\&pg=137\&ac=533\&bb=file. Downloaded: 15 February 2018.

Bower, J. - Christensen, C. (1995): Disruptive Technologies: Catching the Wave. Harvard Business Review, January-February.

Christensen, C.M. (1997): The innovator's dilemma: when new technologies cause great firms to fail. Harvard Business School Press (edit), Boston, Massachusetts, USA.

Deutsche Bundesbank (2017): The role of banks, non-banks and the central bank in the money creation process. Deutsche Bundesbank Monthly Report 13. https://www.bundesbank.de/ Redaktion/EN/Downloads/Publications/Monthly_Report_Articles/2017/2017_04_money_ creation_process.pdf?_blob=publicationFile. Downloaded: 12 March 2018.

DNB (2016): More room for innovation in the financial sector. https://www.dnb.nl/ en/binaries/More-room-for-innovation-in-the-financial\%20sector_tcm47-361364. pdf?2017072902. Downloaded: 15 February 2018. 
DNB (2017): Regulatory sandbox web site. https://www.dnb.nl/en/supervision/ innovationhub/maatwerk-voor-innovatie-regulatory-sandbox/. Downloaded: 27 February 2018.

EBA (2017): Discussion Paper on the EBA's approach to financial technology (FinTech). https:// www.eba.europa.eu/-/eba-publishes-a-discussion-paper-on-its-approach-to-fintech. Downloaded: 27 February 2018.

EBA (2018): The EBA's Fintech Roadmap. http://www.eba.europa.eu/-/eba-publishes-itsroadmap-on-fintech. Downloaded: 27 February 2018.

EC (2017): FinTech: A more competitive and innovative European financial sector. European Commission Consultation Document. https://ec.europa.eu/info/sites/info/files/2017fintech-consultation-document_en_0.pdf. Downloaded: 12 March 2018.

EC (2018): FinTech Action plan: For a more competitive and innovative European financial sector. European Commission. https://ec.europa.eu/info/publications/180308-action-planfintech_en. Downloaded: 20 March 2018.

ECB (2017a): Consultation on guides concerning the assessment of licence applications and fintech credit institution licence applications. https://www.bankingsupervision.europa.eu/ press/pr/date/2017/html/ssm.pr170921.en.html. Downloaded: 27 February 2018.

ECB (2017b): Digital na(t)ive? Fintechs and the future of banking. https://www.ecb.europa.eu/ press/key/date/2017/html/sp170327_1.en.html .Downloaded: 27 February 2018.

European Parliament (2017): Report on FinTech: The influence of technology on the future of the financial sector. Plenary Sitting. http://www.europarl.europa.eu/sides/getDoc. do?pubRef=-//EP//TEXT+REPORT+A8-2017-0176+0+DOC+XML+V0//EN. Downloaded: 10 February 2018.

EY (2016): Transforming talent, The banker of the future. Global banking outlook 2016.

FCA (2015a): Regulatory sandbox web site. https://www.fca.org.uk/firms/regulatory-sandbox. Downloaded: 27 February 2018.

FCA (2015b): FCA web site. https://www.fca.org.uk/firms/authorisation. Downloaded: 27 February 2018.

FSB (2017): Financial Stability Implications from FinTech: Supervisory and Regulatory Issues that Merit Authorities' Attention. 27 June. http://www.fsb.org/wp-content/uploads/ R270617.pdf. Downloaded: 10 February 2018.

Gartner (2017): Research Methodologies: Gartner Hype Cycle. https://www.gartner.com/ technology/research/methodologies/hype-cycle.jsp. Downloaded: 12 March 2018. 
He, D. - Leckow, R.B. - Haksar, V. - Mansini-Griffoli, T. - Jenkinson, N. - Kashima, M. Khiaonarong, T. - Rochon, C. - Tourpe, H. (2017): Fintech and Financial Services: Initial Considerations. IMF Discussion Note, SDN/17/05. https://www.imf.org/en/Publications/ Staff-Discussion-Notes/Issues/2017/06/16/Fintech-and-Financial-Services-InitialConsiderations-44985. Downloaded: 15 February 2018.

KPMG (2018): The Pulse of Fintech - Q4 2017. https://assets.kpmg.com/content/dam/kpmg/ xx/pdf/2018/02/pulse_of_fintech_q4_2017.pdf. Downloaded: 12 March 2018.

Lee, D.K.Ch. - Teo, G.S. (2015): Emergence of FinTech and the LASIC Principles. Journal of Financial Perspectives, 3 (3), 1-26. Research Collection Lee Kong Chian School of Business. https://doi.org/10.2139/ssrn.2668049

MAS (2016): FinTech regulatory sandbox guidelines. http://www.mas.gov.sg/ /media/ Smart\%20Financial\%20Centre/Sandbox/FinTech\%20Regulatory\%20Sandbox\%20 Guidelines.pdf. Downloaded: 15 February 2018.

McKinsey \& Company (2016): FinTechnicolor: The New Picture in Finance. http://www.theblockchain.com/docs/FinTechnicolor-The-New-Picture-in-Finance\%20-\%20Mckinsey.pdf. Downloaded: 10 February 2018.

MNB (2017): Innovation and stability, a FinTech overview in Hungary. Consultation document, Magyar Nemzeti Bank. https://www.mnb.hu/letoltes/consultation-document.pdf. Downloaded: 10 February 2018.

Nagy, M. - Vonnák, B. (2014): Egy jól müködő magyar bankrendszer 10 ismérve (10 features of a well-functioning Hungarian banking sector). https://www.mnb.hu/letoltes/egy-jolmukodo-magyar-bankrendszer-10-ismerve.pdf. Downloaded: 15 February 2018.

Nicoletti, B. (2017): The future of FinTech, Integrating Finance and Technology in Financial Services. Palgrave Macmillan.

Philippon, T. (2016): FinTech Opportunity. NBER Working Paper, No. 22476. https://doi.org/ $10.3386 / \mathrm{w} 22476$

Stevenson, B. - Wolfers, J. (2011): Trust in public institutions over the business cycle. The American Economic Review, 101(3): 281-287.

WEF (2016) The Complex Regulatory Landscape for FinTech. World Economic Forum http://www3.weforum.org/docs/WEF_The_Complex_Regulatory_Landscape_for_ FinTech_290816.pdf. Downloaded: 15 February 2018

Zetzsche, D. - Buckley, R.P. - Arner, D.W. - Barberis, J.N. (2017): Regulating a Revolution: From Regulatory Sandboxes to Smart Regulation. European Banking Institute (EBI) Research Paper Series, 2017-11. https://doi.org/10.2139/ssrn.3018534 